\title{
Port infrastructures and trade: Empirical evidence from Brazil ${ }^{\text {出 }}$
}

\author{
Anna Bottasso $^{\mathrm{a}}$, Maurizio Conti ${ }^{\mathrm{a}, \mathrm{b}}$, Paulo Costacurta de Sa Porto ${ }^{\mathrm{c}}$, Claudio Ferrari ${ }^{\mathrm{a}, *}$, \\ Alessio Tei ${ }^{\mathrm{d}}$

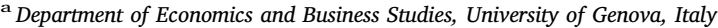 \\ ${ }^{\mathrm{b}}$ European Commission, Joint Research Centre (JRC), Ispra, Italy \\ ${ }^{c}$ Universidade Federal de Sao Paulo, Brazil \\ ${ }^{\mathrm{d}}$ School of Engineering, Newcastle University, UK
}

\begin{abstract}
A B S T R A C T
In this study, we analyse the impact of port infrastructure on trade by estimating a gravity equation for exports (imports) of Brazilian states towards (from) all main Brazil's trading partners. In particular, we consider exports (imports) of the 27 Brazilian states towards (from) 30 of Brazil's most important trading partners over the period 2009-2012. By estimating a set of gravity equations with the Poisson pseudo-maximum likelihood estimator, we find that an increase in port infrastructure (as proxied by the piers extension in each Brazilian state normalized by that state's area) is associated to large increases in Brazilian exports, while the impact on imports is more mixed and generally lower. Our results are robust to controlling for a series of state and country fixed effects.
\end{abstract}

\section{Introduction}

The relation among transport endowment, efficient transport/logistics services and trade is well documented by a number of policy (e.g. Arvis et al., 2012) and scientific (e.g. Limao and Venables, 2001) papers. Several scholars (e.g. Vickerman, 1995; Camagni and Capello, 2013) and international institutions (e.g. World Bank [e.g. Arvis et al., 2012], European Union [e.g. Purwanto, 2010], OECD [e.g. Merk, 2012]) have discussed the potential benefits of an improved infrastructure network and its capability of fostering both regional competitiveness and economic development. Within this framework, it is relevant to highlight the link among the transport infrastructure endowment, the level of regional connectivity, and the international freight flows (e.g. Li and Qi, 2016). Transport network investments aimed at improving connectivity with international markets is an important issue within the debate on expansive policy interventions, especially for those countries whose economic growth is heavily linked to international trade, such as the Latin America and the Caribbean (e.g. Wilmsmeier and Hoffmann, 2008; Calatayud et al., 2017).

Different transport systems - and related infrastructure - affect regional competitiveness and trade openness in a number of ways, as shown by the results of those studies analyzing the role of air transport connectivity (e.g. Graham, 1998), land modal solutions (e.g. Handy, 2005; Coşar and Demir, 2016) and maritime transports (e.g. Wilmsmeier et al., 2006). Moreover, logistics plays an essential role in linking together different transport networks and favoring international production chains (e.g. Bensassi et al., 2015; World Bank, 2012; Hesse and Rodrigue, 2006).

Within this framework, it is important to stress that over $80 \%$ of international trade involves maritime services (Unctad, 2016), giving to port infrastructure a crucial role to improve international connectivity and propensity to international trade for a given

\footnotetext{
The views expressed here are those of the authors and may not in any circumstances be regarded as stating an official position of the European Commission.

* Corresponding author.

E-mail address: ferrari@economia.unige.it (C. Ferrari).
} 
region (e.g. Guerrero et al., 2016; Ducruet and Notteboom, 2012; Ducruet and Itoh, 2016). Moreover, as also underlined by Rodrigue et al. (2016), transport systems are normally represented by networks in which nodal infrastructure (such as ports) plays a key role, by promoting accessibility and fostering local competitiveness for the hosting regions.

Indeed the relationship between transport infrastructure and international trade has been increasingly investigated by the economic literature. The importance of transport endowment for international openness is well documented for all the main transport modes (e.g. Moreno and Lopez-Bazo, 2007; Arbués et al., 2015), with maritime networks playing a major role in fostering international trade (e.g. Martínez-Zarzoso et al. 2003 In particular, a positive influence of sea access on regional export performance, has been highlighted by some studies (e.g. Cizkowicz et al., 2013; Matthee and Naudé, 2008); moreover, spillover effects stemming from maritime regions to landlocked ones are found to favor the exporting activity (e.g. Marquez-Ramos, 2016).

Most studies focus on the effects of port infrastructure, or port related transport systems, on the regional economy (e.g. Hall, 2009; Ng and Gujar, 2009; Bottasso et al., 2013, 2014; Song and van Geenhuizen, 2014; Wang et al., 2017), but only few of them (e.g. Portugal Perez and Wilson, 2012; Celbis et al., 2014; Olarreaga, 2016) try to assess the link between international trade and maritime infrastructure endowment. Hence, it seems that this issue is still under-investigated, despite evidence in favor of this relation is supported at both theoretical and empirical level.

A related issue that has been receiving increasing attention in recent years is the link between transport costs and trade: for instance, Clark et al. (2004) show that port efficiency is an important determinant of shipping costs and that port efficiency differentials can be explained by excessive regulation, the prevalence of organized crime and the country's overall infrastructure endowment. In turn, Haddad et al. (2010) apply a spatial, interregional CGE model to simulate the impacts of increases in port efficiency in Brazil. They evaluate three different scenarios and conclude that in all cases improvements in port efficiency lead to a faster growth, more competitiveness and more openness of the Brazilian economy. Similarly, Tiller and Thill (2017) apply a Trade Impedance Quotient to better evaluate if transport costs are acting as trade barriers in South America, potentially limiting benefits of trade on the related regions. Interestingly, Cassey (2011) focuses on USA exports data observed in 2003 and shows the importance of analyzing the link between the geographical characteristics, as affected by the transport system, and international trade; the author suggests that such analysis provides further insights with respect to the study of transport costs.

The current paper contribute to this literature since we analyse the impact of port infrastructure on trade by estimating a gravity equation with Poisson quasi-maximum likelihood techniques for exports (imports) of Brazilian states towards (from) all main Brazil's trading partners. In particular, we consider exports (imports) of the 27 Brazilian states towards (from) 30 of Brazil's most important trading partners over the period 2009-2012 and we quantify the impact of port infrastructure endowment on the international trade and its distribution over different Brazilian regions.

In terms of econometric identification strategy, we follow the most recent econometric practice to deal with endogeneity and simultaneity concerns in the estimation of gravity equations by including a full set of trading partners fixed effects, which control for any unobserved time-invariant heterogeneity at the level of any possible combination between a Brazilian state and a foreign country. Moreover, in the most extended model specifications we also control for a full set of foreign countries-by-year and Brazilian regionsby-year fixed effects, which in turn control for unobserved time-varying shocks at the level of each foreign country and each Brazilian region (which are the aggregate of various Brazilian states), respectively. In other words, the inclusion of trading partners as well as Brazilian regions-by-year fixed effects, allows us to identify the effects of Brazilian port infrastructure on Brazilian trade by exploiting only port infrastructure variation over time across Brazilian states within a Brazilian region, thereby controlling for the various unobserved determinants of trade and port infrastructure developments in the most possible granular way, given our data. This is a significant improvement in terms of econometric strategy with respect to the previous studies that have attempted to estimate the effect of port infrastructures on trade.

The choice of Brazil is mainly related to its peculiar economic structure and its presence on foreign markets: as underlined by Boehe et al. (2016), Brazilian exports strongly affect local company performance and regional growth. Moreover, the role played by Brazil in the WTO seems to reveal the government's desire to foster Brazilian international visibility (Hopewell, 2015). Despite this, transport policies (e.g. Nuñez and Önal, 2016) and related investment (e.g. Garcia-Escribano et al., 2015) are not always consistent with the objectives of the government and several bottlenecks have been registered in the transport network, with many critical issues related to port activities and freight distribution (e.g. Barros et al., 2015; Galvão et al., 2017). Given the abovementioned scenario, investigating the link between trade and transport infrastructure (mainly ports) in Brazil assumes particular policy relevance.

The paper is organized as follows: Section 2 will focus on the Brazilian framework and on the data used in our analysis. Section 3 is dedicated to the methodology and the description of the econometric strategy. Section 4 discusses empirical results while Section 5 addresses conclusive remarks and focus on policy implications of our analysis.

\section{Data and institutional setting}

During the last decade Brazil has been one of the fastest growing markets and the biggest South American economy: real economic growth averaged more than 3.7\% above the continental value and only in the last couple of years registered a reduction (IMF International Monetary Fund, 2017). Similarly, GDP in purchase power parity pro-capita has registered an almost constant growth in the last 15 years - with only few years of negative records - and an average value of more than 3\%. Most of Brazilian economy is now connected to international trade, being one of the leading export countries for many raw materials as well as finished products. Brazil is one of the two main world suppliers of iron ore and coal and also one of the top leading countries in export of other primary sector outcomes, being the third exporter of agricultural products as well as the first chemical industry producer of the southern hemisphere (OECD, 2016). According to IMF statistics (2017), the value of exported goods has increased 8 times in the last thirty years, with 
Table 1

Brazilian main commodity Exports and Imports by HS Group, in 2016.

Source: Own elaboration from Comtrade database, 2017

\begin{tabular}{|c|c|c|}
\hline HS code & HS Chapter Description & Value US\$ \\
\hline \multicolumn{3}{|l|}{ Export } \\
\hline 12 & Oil seeds and oleaginous fruits; miscellaneous grains, seeds, etc. & $19,557,937,674$ \\
\hline 26 & Ores, slag and ash. & $15,816,098,724$ \\
\hline 02 & Meat and edible meat offal. & $12,655,793,496$ \\
\hline 84 & Nuclear reactors, boilers, machinery and mechanical appliances; parts thereof. & $11,647,180,661$ \\
\hline 27 & Cocoa and cocoa preparations. & $11,581,277,848$ \\
\hline 87 & Vehicles other than railway or tramway rolling-stock, and parts and accessories thereof. & $10,971,032,674$ \\
\hline 17 & Sugars and sugar confectionery. & $10,585,664,649$ \\
\hline 72 & Iron and steel. & $7,892,012,402$ \\
\hline 47 & Pulp of wood or of other fibrous cellulosic material; recovered (waste and scrap) paper or paperboard. & $5,575,278,935$ \\
\hline 23 & Residues and waste from the food industries; prepared animal fodder. & $5,538,918,337$ \\
\hline \multicolumn{3}{|l|}{ Import } \\
\hline 84 & Nuclear reactors, boilers, machinery and mechanical appliances; parts thereof. & $21,124,300,180$ \\
\hline 85 & Electrical machinery and equipment and parts thereof, etc. & $16,942,608,828$ \\
\hline 27 & Cocoa and cocoa preparations. & $15,142,175,558$ \\
\hline 87 & Vehicles other than railway or tramway rolling-stock, and parts and accessories thereof. & $9,955,443,182$ \\
\hline 29 & Organic chemicals. & $8,327,954,364$ \\
\hline 30 & Pharmaceutical products. & $6,389,498,894$ \\
\hline 31 & Fertilisers. & $6,002,709,569$ \\
\hline 39 & Plastics and articles thereof. & $5,916,006,970$ \\
\hline 90 & Optical, photographic, cinematographic, measuring, checking, precision, medical or surgical instruments and apparatus, etc. & $4,757,979,125$ \\
\hline 38 & Miscellaneous chemical products. & $3,810,338,458$ \\
\hline
\end{tabular}

import values that have grown even more.

The incredible growth of Brazil has put under severe stress the transport system, with a registered increase of inefficiencies (e.g. Barros et al., 2015) and critical conditions of main transport infrastructure. Since seaports are the main gateway to foreign markets, maritime related infrastructure are of particular importance in order to support and favor the growth process.

According to the AAPA database (American Association of Port Authorities, 2017), in 2016, 63\% of Brazilian international maritime transport - in tons - was generated by dry bulk cargo, mainly iron ore and soybeans exports to China. However, containerized cargo accounted for only $10 \%$ of the total handled tons, thus showing the relative small size of the Brazilian container port industry. Table 1 shows the main traded cargo by sea: freight bulk accounts also for most of the traded value for both import and export. The first ten traded cargoes (shown in Table 1) represented $60 \%$ of the 2016 value of the Brazilian export and $71 \%$ of the import.

Fig. 1 shows main ports related trends in relation to Brazilian seaport activity over the period 2005-2016 for both the seaborne trade and the main handled cargo categories. It can be observed that dry bulk has experienced a stable growth until 2015 (with the

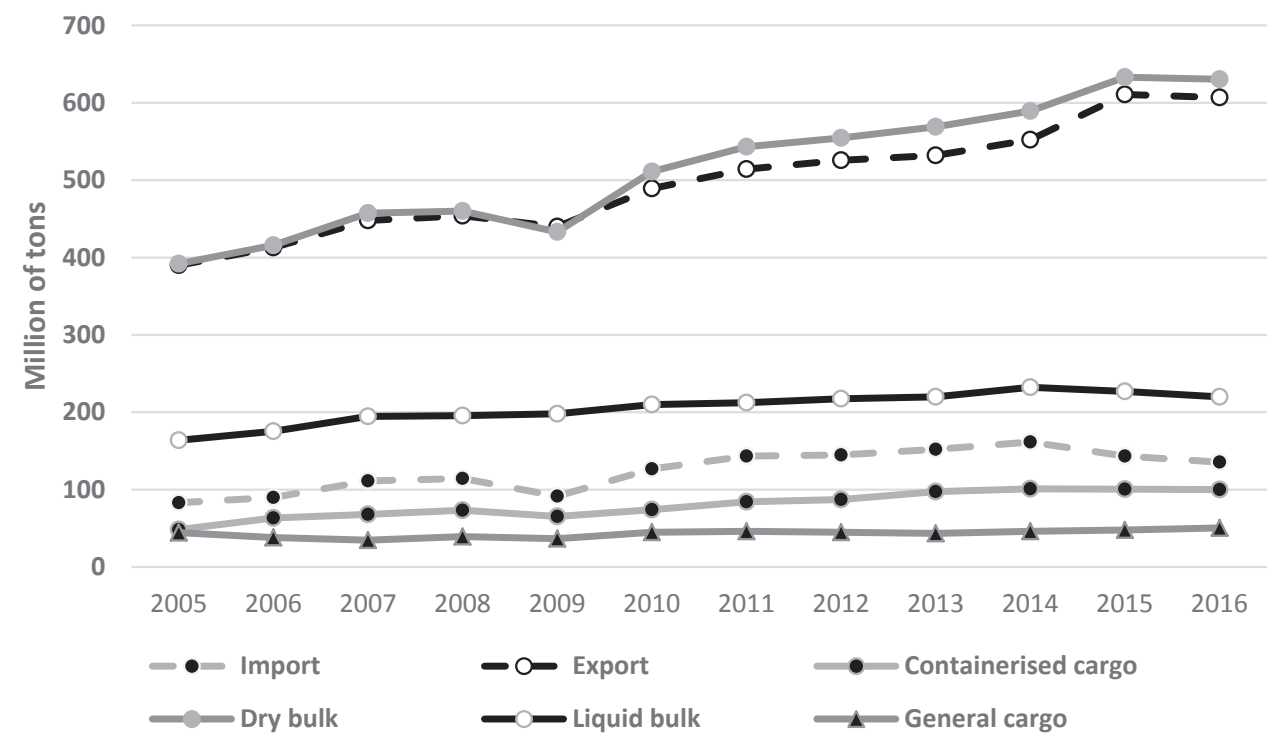

Fig. 1. Brazilian ports trends.

Source: own elaboration from ANTAQ data, 2017 
exception of the 2008-2009 reduction due to the international financial crisis) and a similar pattern is observed for containerized cargo, which still represents a low share of the overall activity.

Such picture is likely to be related to the import/export unbalance situation of the country. Indeed dry bulk activities are related to export flows, while container traffic is mainly related to import flows linked to the demand for finished products.

Despite the fast growth rate of the Brazilian international trade, the deficiencies of the country in terms of infrastructural endowment and its management are described in several research papers that evaluate the high costs of the Brazilian logistics (e.g. Wanke and Zinn, 2004; Fleury and Hijjar, 2008) and maritime systems (e.g. Wanke et al., 2011; Wanke, 2013).

The Logistics Performance Index [LPI] (World Bank, 2017a) has constantly grown until 2010, while in the last six years it registered a reduction in its overall value (from 2.75 in 2007 to 3.20 in 2010 to 3.09 in 2016). This decrease is mainly due to the index component related to logistics, while the infrastructure endowment component has been stable during the past 7 years. Nevertheless, Brazil registered one of the highest LPI value in South America, despite other developing countries of the region (e.g. Chile) are currently registering both higher values and faster growth trends. However, Brazil scores poorly in the Doing Business Indicators (World Bank, 2017b) ranking 123 out of 190 considered countries, with particular issues in terms of administrative procedures related to international trade (in which rank 149th worldwide). Such poor performance might have negatively impacted the performance of the Brazilian transport system.

In order to enhance the level of competitiveness and efficiency of Brazilian ports, governmental bodies have implemented several policy interventions (e.g. Galvão et al., 2017). However such actions have had limited success, mainly because of the lack of continuity in the implementation of plans aimed at improving the country's logistics system and the insufficient coordination among transport policies, as for the case of the Short Sea Shipping solution (e.g. Sá Porto et al., 2014). Indeed Ng et al. (2013) underline that a lack of coordination among different Brazilian transport authorities and logistics stakeholders, together with the presence of institutional barriers, limite the development of an efficient transport system. In accordance with the authors' findings, current practices generate deficiencies that hinder the integration among different transport and logistics systems in Brazil. These barriers negatively affect most of the international trade operations, generating bias due to the "face-to-face" operations (e.g. custom clearance) that also affect the reliability of the overall transport system.

Thus, despite the importance of international trade for the Brazilian economy, the infrastructure that serve foreign freight flow as well as their management - still suffer from several critical issues. Interestingly, in spite of the overall length of the Brazilian coast line (i.e. over $7000 \mathrm{~km}$ ), cargo movement in seaports is quite concentrated, with the port of Santos alone handling around $30 \%$ of the overall Brazilian total cargo volume, and only other two ports overpass the 10\% quota (ANTAQ, 2017). From a geographical point of view, the majority of main ports are located in the South and only a few harbors serve the northern part of the country (mainly in relation of iron ore export flows). Such distribution increases the pressure to the land transportation system and generates potential bottlenecks in order to serve regions far from the shoreline (as demonstrated, for instance, by the severe congestion registered on the road between Santos - the main national port - and Sao Paulo - the most populated and industrialized area of the country). According to the Central Intelligence Agency (CIA) Factbook (2017), Brazil currently registers over 28,000 km of rail network but only a small percentage is actually electrified (around 3\%) and 4 different gauges are present, limiting long distance trips and efficient intermodal transport. Similarly, road transport quality is relatively low, with about $80 \%$ of the road network being unpaved, with only one-fifth of the road network being paved and only few main road corridors (CNT, 2016).

The abovementioned country's characteristics underline both the importance of trade in the Brazilian economy and the different role of main transport infrastructure in fostering freight flows distribution, with ports having a strategic role for Brazilian companies.

\subsection{The database}

Brazil is a federation composed by 27 states, the majority of them directly facing the sea (Fig. 2), even though the concentration of main ports in the South does not assure an equal access to maritime services to the different maritime regions.

In order to perform the analysis, for each Brazilian state - equivalent to TL2 OECD geographical aggregation - trade data relative to the main trading partners (30 countries, covering $80 \%$ of the Brazilian import and export flows) have been collected for the period 2009-2012. Main economic, social and infrastructure related variables have been taken into consideration, as resumed in Table 2.

The geographical distribution of foreign trade, GDP, population and trade across states is represented in Fig. 3 that shows how such distributions are concentrated in few areas of the country. The main 5 states (i.e. Sao Paulo, Rio de Janeiro, Minas Gerais, Parana, and Rio Grande du Sul) account for more than $65 \%$ of the distribution of all main economic indicators, and for about $40 \%$ of the population. Considering foreign partners, it is important to underline that all main partners (with the partial exception of Argentina) are far from the South American continent, so that the presence of an adequate maritime infrastructure system becomes crucial.

Table 3 shows the distribution per State of main port related characteristics, highlighting a relative difference in the port endowment, with main port facilities located in three regions (e.g. Sao Paulo, Rio de Janeiro, and Rio Grande do Sul). Despite this, all Brazilian maritime regions register the presence of developed port facilities as well as relevant physical characteristics in terms of draft.Table 4 resumes descriptive statistics of the variables used in the empirical analysis for Brazilian states only and suggest the existence of huge differences among them, in all the considered indicators. The high variance of the variables is a proof of the unbalanced situation within the country as far as economic, social and endowment indicators is concerned. It is also interesting to underline that infrastructure endowments exhibits a variation (even if small) over time, probably associated to the high infrastructure investment in some key regions planned by the government in order to meet the growing demand (e.g. Barros et al., 2015).

Table 5 in turn shows the spatial concentration of the main economic and infrastructure related variables over the Brazilian 


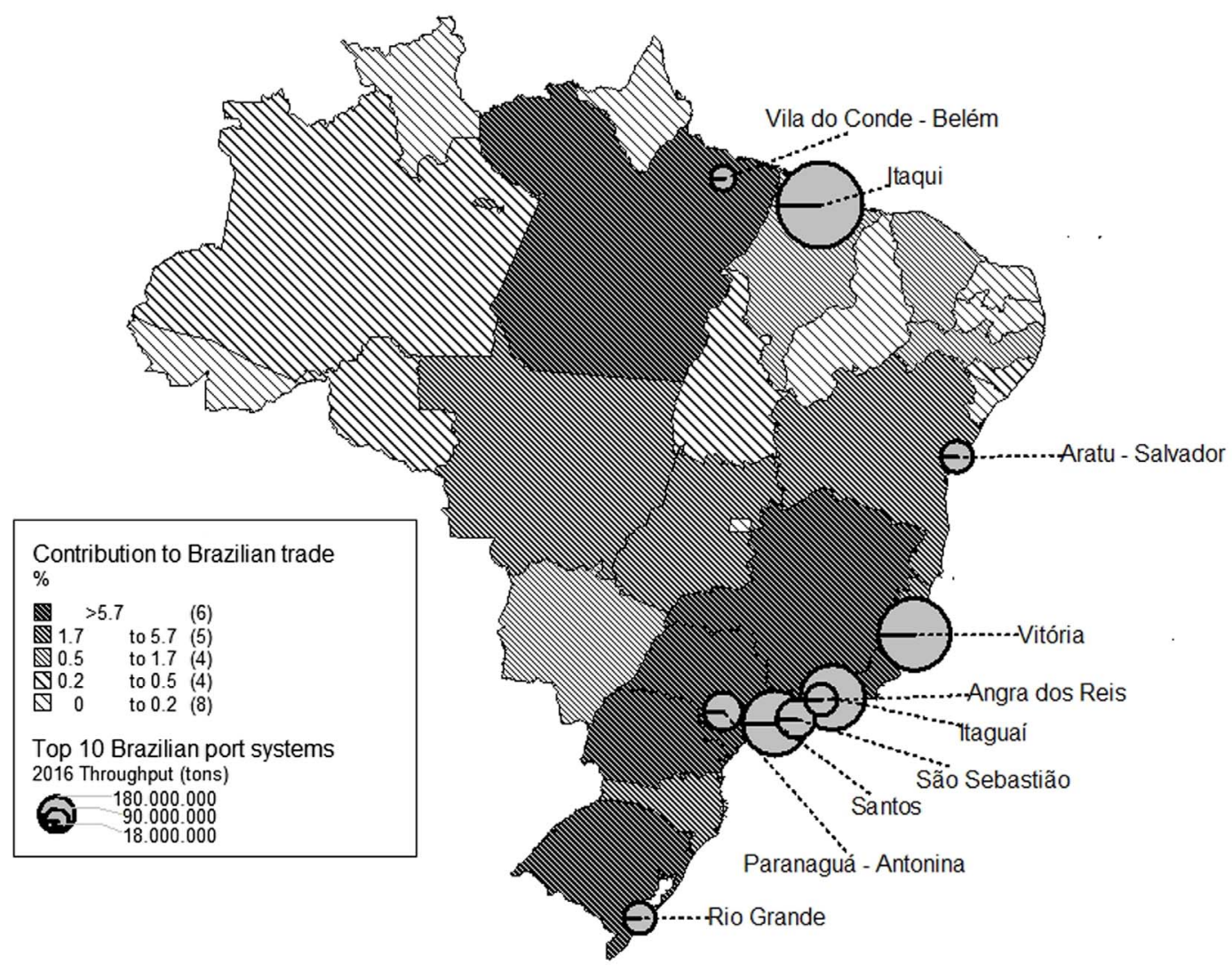

Fig. 2. Contribution of Federal States to Brazilian trade.

Source: own elaboration from ANTAQ data, 2017

Table 2

Collected variables.

Sources: MDIT - Ministry of Development, Industry and Trade; Brazilian Statistical Office; WB - World Bank; World Atlas PC; WTO - World Trade Organization; CNT Road Research; ANTAQ - Port regulator in Brazil; ANAC - airport regulator in Brazil; ANTF - Rail regulator in Brazil, various years

\begin{tabular}{|c|c|c|c|}
\hline Variable & Description & Source & Unit \\
\hline Trade & Trade (exports or imports) between the 27 Brazilian state and a partner country ( 30 countries). & MDIT & US\$ \\
\hline GDP-1 & Gross Domestic Product (GDP) of a Brazilian state (or a partner country) & Brazilian Statistical Office & US\$ \\
\hline GDP-2 & Gross Domestic Product (GDP) of a partner country (or a Brazilian state) & Brazilian Statistical Office & US\$ \\
\hline Pop-1 & Population of a Brazilian state (or a partner country) & Brazilian Statistical Office & $\mathrm{mln}$ \\
\hline Pop-2 & Population of a partner country (or a Brazilian state) & WB & $\mathrm{mln}$ \\
\hline Distance & Distance between the capital of a Brazilian state and the capital of a partner country & World Atlas PC & $\mathrm{km}$ \\
\hline Adjacency & Whether the Brazilian state and the partner country share a common border & World Atlas PC & Dummy \\
\hline Mercosur & Whether the partner country belongs to the Mercosur preferential trade agreement & WTO & Dummy \\
\hline Nafta & Whether the partner country belongs to the North America Free Trade Area trade agreement & WTO & Dummy \\
\hline EU & Whether the partner country belongs to the European Union trade agreement & WTO & Dummy \\
\hline Road & Total road extension in a Brazilian state & CNT Road Research & $\mathrm{km}$ \\
\hline Road Quality & Total road extension in a Brazilian state that are classified as good or excellent by CNT & CNT Road Research & $\mathrm{km}$ \\
\hline Road Ext & Total road extension in a Brazilian state divided by the state's total area & CNT Road Research & $\mathrm{km}$ per sqm \\
\hline Road Quality-Ext & $\begin{array}{l}\text { Total road extension in a Brazilian state that are classified as good or excellent by CNT divided } \\
\text { by the state's total area }\end{array}$ & CNT Road Research & $\mathrm{km}$ per sqm \\
\hline Cais & The indicator shows the total quay or pier extension in ports of a Brazilian state & ANTAQ & $\mathrm{m}$ \\
\hline Cais Ext & Total quay or pier extension in ports of a Brazilian state divided by the state's total area & ANTAQ & m per sqm \\
\hline Calado & Average depth of all ports in a Brazilian state & ANTAQ & $\mathrm{m}$ \\
\hline Aero & Total length of airports in a Brazilian state & ANAC & $\mathrm{m}$ \\
\hline Aero Ext & Total extension of airports in a Brazilian state divided by the state's total area & ANAC & m per sqm \\
\hline Ferro & Total rail extension in a Brazilian state & ANTF & $\mathrm{km}$ \\
\hline Ferro Ext & Total rail extension in a Brazilian state divided by the state's total area & ANTF & $\mathrm{km}$ per sqm \\
\hline
\end{tabular}


FOREIGN TRADE - BRAZILIAN STATES

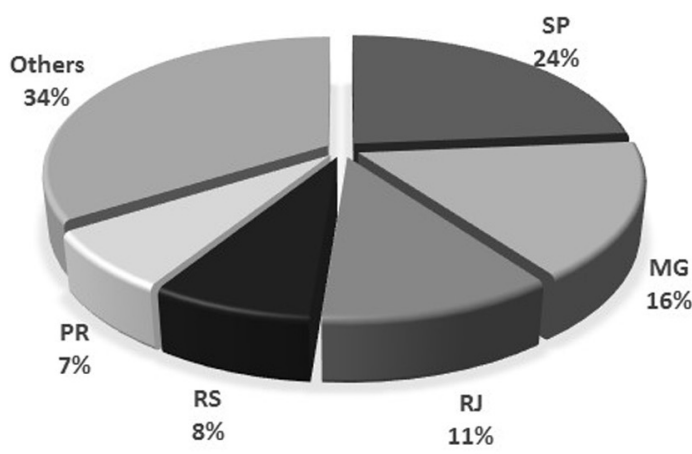

POPULATION - BRAZILIAN STATES

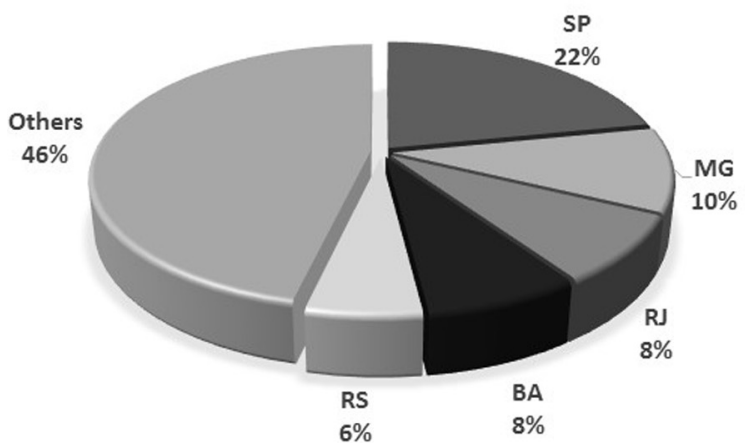

GDP - BRAZILIAN STATES

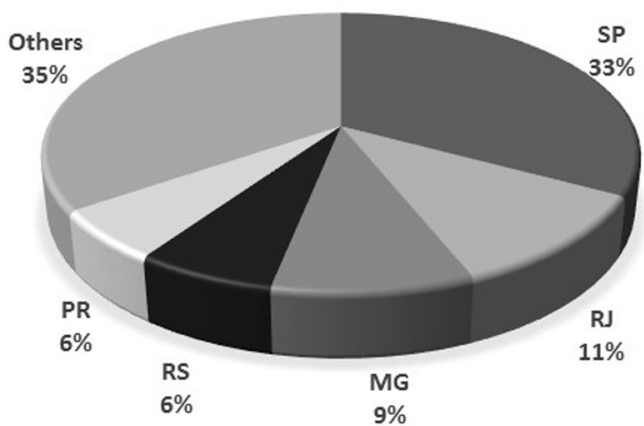

TRADE - MAIN INTERNATIONAL PARTERNS

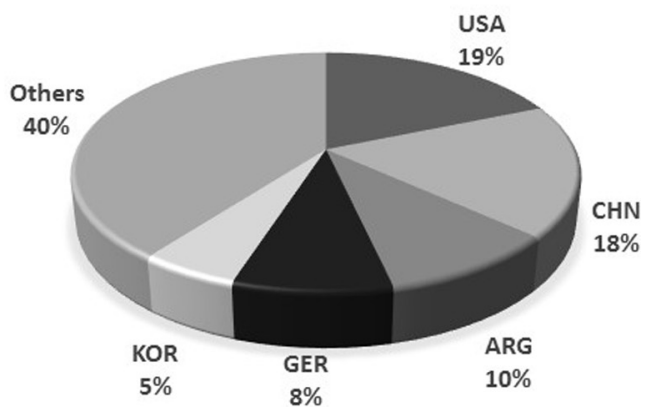

Fig. 3. Geographical distribution of the main economic and social variables..

Source: MDIT and Brazilian Statistical Office, 2017. SP - Sao Paulo; MG - Mina Gerais; RJ - Rio de Janeiro; BA - Bahia; RS - Rio Grande so Sul; PR - Parana

States. The concentration is measured using the Herfindhal-Hirschmann Indicator (HHI) over the different Brazilian States. On the one hand, nodal infrastructures (i.e. airport and ports) are spatially concentrated - if the State extension is taken into consideration given their role in the local economies and their needs in terms of location and connected regions. On the other hand, network infrastructures (i.e. rail and road) are either not concentrated (roads, even considering their quality) or slightly concentrated (rail). Moreover, the main economic indicators (i.e. GDP and trade) are slightly concentrated (and this is mainly connected to the economic leading role of specific regions, such as Sao Paulo) while the population is fairly spread over the country.

\section{Econometric strategy}

The estimation of gravity equations has a long tradition in the empirical trade literature, at least since the pioneering work of Tinbergen (1962), but only recently they have been micro-founded, i.e. explicitly derived from microeconomic theory. In particular, various trade theories (Head and Mayer, 2015) have shown that bilateral trade flows $T_{i j}$ (i.e. exports of country $i$, the origin country, to country $j$, the destination country) can be expressed, in a cross sectional context, as in Eq. (1) ${ }^{1}$ :

$$
T_{i j}=\frac{Y_{i}}{\Pi_{i}^{-\phi}} \frac{E_{j}}{\mathrm{P}_{j}^{-\phi}} D_{i j}^{-\phi}
$$

where $Y_{i}$ represents total output of the origin country, $E_{j}$ total expenditure in the destination country (both usually proxied by GDP), $D_{i j}$ is a vector of variables that might affect trade costs between any pair of countries, such as distance, common languages, barriers to trade, infrastructure, customs unions, etc., while $\phi$ represents the elasticity of trade flaws with respect to trade costs. In turn, $\Pi_{i}$ and $\mathrm{P}_{j}$ represents the inward and outward multilateral resistance indexes introduced by Andreson and van Wincoop (2003), that capture the general equilibrium effects in trade. ${ }^{2}$ In particular, the authors show that these multilateral indexes, associated to a country market potential and degree of openness to trade, are functions of trade costs (see for a nice exposition Fally (2015)).

\footnotetext{
${ }^{1}$ Eq. (1) can be derived also from those new economic geography type of models featuring transportation costs and transportation infrastructures recently reviewed by Redding and Turner (2017). For instance, Duranton (2015) studies the effects of roads within and between cities on the level of trade for a sample of Colombian cities. He shows that a $10 \%$ increase in the stock of highways within a city is associated to a $3-5 \%$ increase in both the value and weight of exports.

${ }^{2}$ It can be shown (Baldwin and Taglioni, 2006) that $\mathrm{P}_{j}$ is the CES ideal price index in the destination country, while $\Pi_{i}$ is a function of trade costs. See also Head and Mayer (2015).
} 
Table 3

Brazilian port endowment.

Source: Own elaboration on ANTAQ data

\begin{tabular}{|c|c|c|c|c|c|c|c|c|}
\hline \multirow[t]{2}{*}{ Brazilian States } & \multicolumn{4}{|c|}{ Quay (m) } & \multicolumn{4}{|c|}{ Draft $(m)$} \\
\hline & 2009 & 2010 & 2011 & 2012 & 2009 & 2010 & 2011 & 2012 \\
\hline Acre & 0 & 0 & 0 & 0 & 0 & 0 & 0 & 0 \\
\hline Alagoas & 1057 & 1057 & 1057 & 1057 & 10.5 & 10.5 & 10.5 & 10.5 \\
\hline Amapá & 0 & 0 & 0 & 0 & 0 & 0 & 0 & 0 \\
\hline Amazonas & 621 & 621 & 621 & 621 & 10 & 10 & 10 & 10 \\
\hline Bahia & 3410 & 3410 & 3410 & 3410 & 33 & 33 & 33 & 33 \\
\hline Ceará & 1050 & 1054 & 1054 & 1054 & 10.3 & 10.3 & 10.3 & 10.3 \\
\hline Distrito Federal & 0 & 0 & 0 & 0 & 0 & 0 & 0 & 0 \\
\hline Espírito Santo & 1970 & 1970 & 1970 & 1970 & 10.67 & 10.67 & 10.67 & 10.67 \\
\hline Goiás & 0 & 0 & 0 & 0 & 0 & 0 & 0 & 0 \\
\hline Maranhão & 1616 & 1616 & 1616 & 1936 & 9.7 & 9.7 & 11.5 & 11.5 \\
\hline Mato Grosso & 0 & 0 & 0 & 0 & 0 & 0 & 0 & 0 \\
\hline Mato Grosso do Sul & 0 & 0 & 0 & 0 & 0 & 0 & 0 & 0 \\
\hline Minas Gerais & 0 & 0 & 0 & 0 & 0 & 0 & 0 & 0 \\
\hline Pará & 2994 & 3092 & 3092 & 3092 & 29.5 & 29.5 & 29.5 & 29.5 \\
\hline Paraíba & 602 & 602 & 602 & 602 & 11 & 11 & 11 & 11 \\
\hline Paraná & 3131 & 3131 & 3131 & 3315 & 21.1 & 21.1 & 21.1 & 21.1 \\
\hline Pernambuco & 4545 & 5815 & 5815 & 5815 & 26 & 26 & 27 & 27 \\
\hline Piauí & 0 & 0 & 0 & 0 & 0 & 0 & 0 & 0 \\
\hline Rio de Janeiro & 9420 & 9420 & 10,030 & 10,070 & 61.4 & 61.4 & 61.4 & 61.4 \\
\hline Rio Grande do Norte & 938 & 938 & 938 & 938 & 25 & 25 & 25 & 25 \\
\hline Rio Grande do Sul & 12,032 & 12,562 & 12,562 & 12,562 & 25.68 & 25.68 & 26.5 & 26.5 \\
\hline Rondônia & 0 & 0 & 0 & 0 & 0 & 0 & 0 & 0 \\
\hline Roraima & 0 & 0 & 0 & 0 & 0 & 0 & 0 & 0 \\
\hline Santa Catarina & 2602 & 3132 & 3215 & 3215 & 34.1 & 34.1 & 36.6 & 36.6 \\
\hline São Paulo & 11,947 & 11,947 & 12,505 & 12,505 & 26.3 & 26.3 & 27 & 27 \\
\hline Sergipe & 0 & 0 & 0 & 0 & 0 & 0 & 0 & 0 \\
\hline Tocantins & 0 & 0 & 0 & 0 & 0 & 0 & 0 & 0 \\
\hline
\end{tabular}

Source: Own elaboration on ANTAQ data

This has important implications for the econometric estimation of gravity equations. Indeed, traditionally a restricted version of Eq. (1) was estimated, namely one omitting the multilateral resistance indexes. However, because they are a function of all determinants of trade costs, their omission generates a correlation between the error term and the included regressors in the vector $D_{i j}$. In fact, simply controlling for some of the determinants of market potential and trade costs, such as distance or GDP, is not likely to be enough in order to remove any correlation between the included variables and the error term, given the difficulty in observing some of these factors.

Most of the recent empirical literature has therefore tackled the omitted variable bias affecting the estimation of "first generation" or "naïve" versions of gravity equation by augmenting the latter with origin and destination country fixed effects, as in Eq. (2) below, where $d_{i}$ and $d_{j}$ are fixed effects for country $i$ and $j$, respectively ${ }^{3}$ :

$$
T_{i j}=Y_{i} E_{j} D_{i j}^{-\phi} \exp \left(\varphi_{i} d_{i}+\varphi_{j} d_{j}\right)
$$

Since multilateral resistance terms can be time varying, when panel data are available, regressions with exporter-importer fixed effects, exporter-by-year and importer-by-year fixed effects can be estimated, as suggested by Baldwin and Taglioni (2006):

$$
T_{i j t}=Y_{i t} E_{j t} D_{i j t}^{-\phi} \exp \left(\varphi_{i} d_{i t}+\varphi_{j} d_{j t}+\varphi_{i j} d_{i j}\right)
$$

where $d_{i t}$ and $d_{j t}$ represent country of origin and destination fixed effects that are allowed to vary over time, while $d_{i j}$ represent fixed effects for any combination of countries of origin and destination.

Traditionally, Eqs. (2) and (3) have been brought to the data by log-linearization and estimated with OLS. However, this approach creates possible important econometric problems as highlighted by Santos Silva and Tenreyro (2006). First, in some trade datasets there is a non-negligible share of observations with zero trade: in this case researchers either dropped entirely these observations or transformed the data by adding $1 \$$ to the trade variable in order to be able to take logarithms, even if this procedure might generate non negligible bias in parameter estimates. ${ }^{4}$ Moreover, the authors show that, in the presence of heteroscedasticity, the estimates of parameters of log-linearized models are biased. This can be seen by noting that the stochastic version of (3) is the following equation (where $\eta_{i j t}$ is an error term):

\footnotetext{
${ }^{3}$ See Head and Mayer (2015) for other, more structural", estimation approaches.

${ }^{4}$ Indeed, zero trade data are not random as they are more likely in the case of small countries that are more distant from each other. See Santos Silva and Tenreyro (2006) for a discussion.
} 


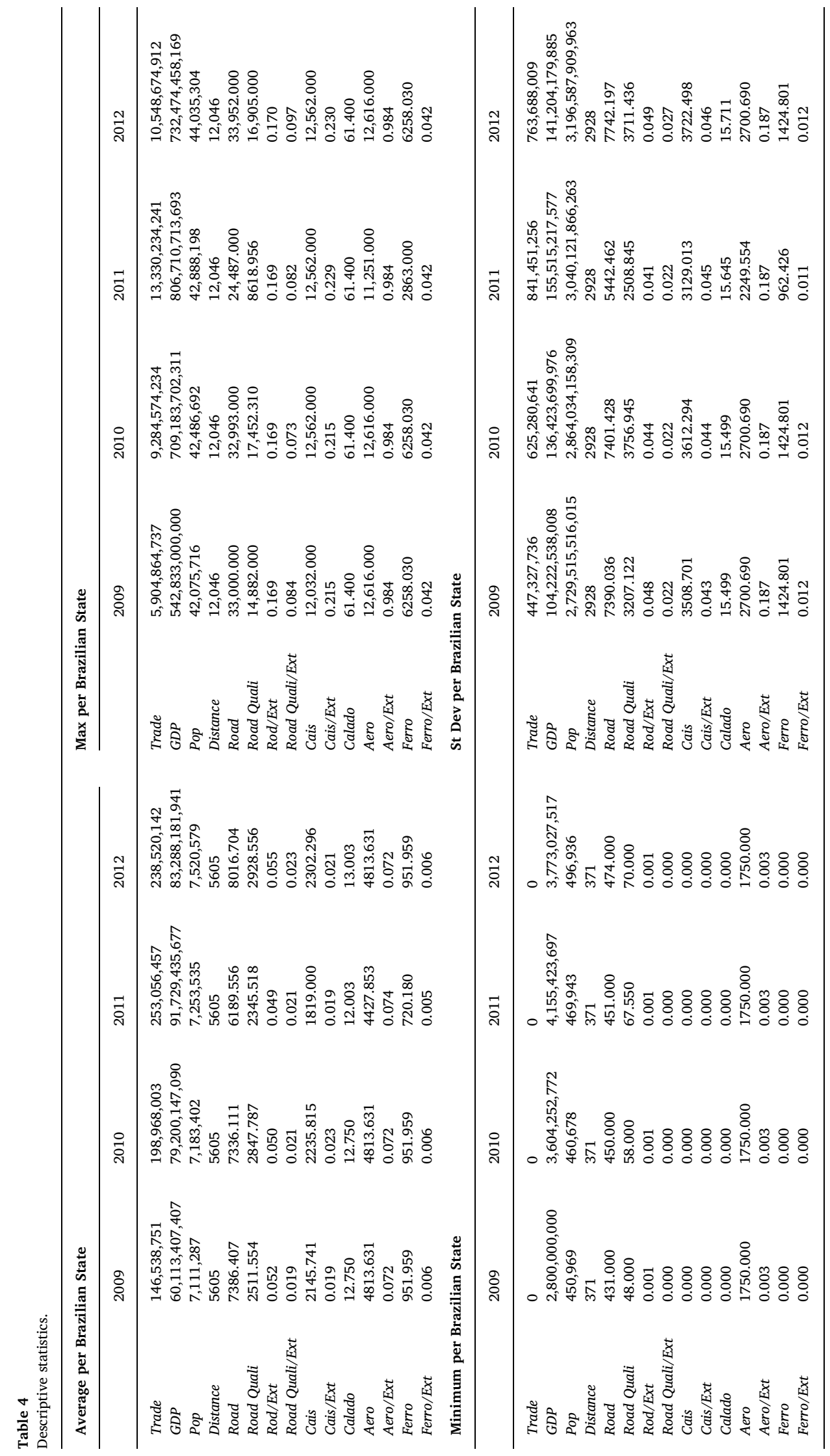


Table 5

Spatial concentration of main used indicators.

Source: Own elaboration

\begin{tabular}{llllllll}
\hline HHI & Airport & Railway & $\begin{array}{l}\text { Road } \\
\text { quality }\end{array}$ & Road/ext & Quay/ext & Airport/ext & Railway/ext \\
\hline 2009 & 482.64 & 1169.32 & 951.93 & 672.48 & 2080.78 & 2777.10 & 1605.11 \\
2010 & 482.64 & 1169.32 & 991.10 & 642.66 & 1601.89 & 2777.10 & 1605.11 \\
2011 & 469.00 & 1056.27 & 861.37 & 640.49 & 2122.22 & 2751.86 & 1620.19 \\
2012 & 482.64 & 1169.32 & 943.20 & 659.44 & 2069.62 & 2777.10 & 1605.11 \\
HHI & Trade & GDP & Pop & Road & Quay & Port draft & HHI $<1200-$ no concentration; HHI $\geq 1200-$ light concentration; \\
2009 & 1279.20 & 1482.31 & 893.54 & 727.37 & 1324.01 & 897.38 & HHI $\geq 1800-$ concentration \\
2010 & 1250.05 & 1466.55 & 892.02 & 733.40 & 1301.35 & 897.38 & \\
2011 & 1212.46 & 1433.60 & 890.57 & 687.56 & 1270.38 & 897.18 & \\
2012 & 1182.26 & 1433.60 & 873.46 & 703.02 & 1302.75 & 891.09 & \\
\hline
\end{tabular}

$$
T_{i j t}=Y_{i t} E_{j t} D_{i j t}^{-\phi} \exp \left(\varphi_{i} d_{i t}+\varphi_{j} d_{j t}+\varphi_{i j} d_{i j}\right) \eta_{i j t}
$$

Authors show that the log-linearization of Eq. (4) does not entail biases, as long as $\ln \eta_{i j t}$ is statistically independent from the included regressors. However, because the expected variable of the logarithm of a random variable depends both on the mean and higher moments of its distribution, if the conditional variance of $\eta_{i j t}$ depends on the included regressors, then the expected value of $\ln \eta_{i j t}$ would depend on the regressors too, thus introducing a bias in parameter estimates. Santos Silva and Tenreyro (2006) propose to address the bias associated to log-linearization of models like those in Eq. (5) by considering exponential models of the form $y=\exp (x \beta)$, which would give raise, in our case, to:

$$
T_{i j t}=\exp \left(\ln \left(Y_{i t} E_{j t}\right)-\phi \ln D_{i j t}+\varphi_{i} d_{i t}+\varphi_{j} d_{j t}+\varphi_{i j} d_{i j}\right) \eta_{i j t}
$$

where $\eta_{i j t}$ is an error term and in the $D_{i j t}$ vector there might be both variables that are entered linearly or in exponential form. ${ }^{5}$ Authors argue that an efficient estimator is a pseudo maximum likelihood estimator based on the assumption that the conditional variance is proportional to the conditional mean, such as the Poisson pseudo maximum likelihood. ${ }^{6}$ Moreover, Fally (2015) shows that the estimation of gravity equations with the Poisson pseudo maximum likelihood estimator and fixed effects fully captures the multilateral resistance terms. ${ }^{7}$

In this study we follow Santos Silva and Tenreyro (2006) and we estimate various versions of Eq. (5). In particular, in our most extended specification, we estimate the following equation with Poisson pseudo maximum-likelihood approach:

$$
T_{i j t}=\exp \left(\ln \left(Y_{i t} Y_{j t}\right)+\ln \left(P_{i t} P_{j t}\right)+\phi P I_{i t}+\varphi_{i} d_{z t}+\varphi_{j} d_{j t}+\varphi_{i j} d_{i j}\right) \eta_{i j t}
$$

where $T_{i j t}$ stands for exports (imports) of Brazilian state $\mathrm{i}$ in year t towards (from) a trade partner country $\mathrm{j}$; $P I_{i t}$ stands for port infrastructure in the Brazilian state $i$ in year $t,{ }^{8}$ while $Y_{i t}, P_{i t}$ and $Y_{j t}, P_{j t}$ are GDP and population in Brazilian state $i$ in year $t$ and GDP and population in country $j$ in year $t$, respectively.

Moreover, in some specifications, where we do not control for state-country pair fixed effects, we also include standard controls in gravity equations, such the log of distance and dummies for countries belonging to specific trade areas, such as Mercosul, EU or Nafta, and a dummy for adjacent country-states. ${ }^{9}$

As it is apparent from Eq. (6) and the above discussion, we deal with the most challenging identification assumptions underlying the estimation of a gravity equation, highlighted by authors such as Andreson and van Wincoop (2003), by including various sets of fixed effects. For instance, in the export regressions our most extended specification controls for exporter-importer fixed effects $\left(d_{i j}\right)$, importer-by-year fixed effects $\left(d_{j t}\right)$ and Brazilian region-by-year fixed effects $\left(d_{z t}\right)$.

Indeed, as highlighted by Baldwin and Taglioni (2006), exporter-importer fixed effects account for any unobserved time invariant heterogeneity (potentially correlated with the included regressors) at the level of each exporter-importer combination. This can be associated to the existence of bilateral tariffs and non-tariff barriers to trade, distance differentials, existence of a common border, state level differences in the share of migrants from various trading partners, state level differences in Brazilian migrants towards specific trading partners, ${ }^{10}$ etc. In turn, in the export (import) regression, importer (exporter)-by-year fixed effects account for unobserved time-varying macroeconomic developments in each foreign country (such as changes in tariffs, economic policies, etc.), or changes in transport infrastructure, etc.

Finally, because our variable of interest (port infrastructure, $P I_{i t}$ ) varies only within Brazilian states over time, we cannot include the Brazilian states time varying fixed effects (the $d_{i t}$ in Eq. (4)), because we would not be able to identify the impact of port

\footnotetext{
${ }^{5}$ In other words, we may consider both linear and log-linear regressors.

${ }^{6}$ It is important to note that, because the authors propose a pseudo maximum likelihood estimator, the distribution of the dependent variable need not to be Poisson at all.

7 See Egger and Staub (2016) for a comparison with alternative pseudo maximum likelihood estimators, such as the negative binomial and the gamma.

${ }^{8}$ Ports enter linearly into Eq. (6) because in some Brazilian states there are no ports. We prefer this approach rather than add 1 to $P I_{i t}$ and then take logs.

${ }^{9}$ In all regressions we also control for the road network.

${ }^{10}$ For the role that local communities of migrants play in shaping the export and imports of the host country, see Bratti et al. (2014), among the others.
} 
Table 6

Regression results for export.

\begin{tabular}{|c|c|c|c|c|c|c|c|c|}
\hline VARIABLES & (1) Export & (2) Export & (3) Export & (4) Export & (5) Export & (6) $\operatorname{Ln}(1+$ Export $)$ & (7) Export & (8) Export \\
\hline \multirow[t]{2}{*}{ lnroad_ext } & $-0.177^{* * *}$ & -0.109 & $-0.111^{*}$ & $-0.162^{* * * *}$ & 0.0238 & -0.141 & 0.0233 & \\
\hline & $(0.0706)$ & $(0.0717)$ & $(0.0593)$ & $(0.0546)$ & $(0.0655)$ & $(0.183)$ & $(0.0655)$ & \\
\hline \multirow[t]{2}{*}{ PI } & 1.317 & $23.19^{* * * k}$ & $24.06^{* k *}$ & $24.53^{* \ldots / k}$ & $25.11^{k \ldots k}$ & -17.02 & $25.11^{* k *}$ & \\
\hline & $(1.368)$ & $(4.449)$ & $(4.589)$ & $(4.927)$ & (5.113) & (16.97) & $(5.114)$ & \\
\hline \multirow[t]{2}{*}{ lngdp1_lngdp2 } & $0.791^{\text {*k*k }}$ & $0.149 *$ & $0.196 * *$ & $0.112 * *$ & $0.0675^{* *}$ & 0.280 & $0.0679^{* *}$ & \\
\hline & $(0.0790)$ & $(0.0767)$ & $(0.0799)$ & $(0.0445)$ & $(0.0269)$ & $(0.347)$ & $(0.0272)$ & \\
\hline \multirow[t]{2}{*}{ lnpop1_lnpop2 } & $0.191^{* *}$ & 1.032 & $1.662^{* * * *}$ & $1.629^{* * * k}$ & 0.295 & 1.039 & 0.299 & \\
\hline & $(0.0973)$ & $(0.670)$ & $(0.598)$ & $(0.553)$ & $(0.402)$ & $(0.881)$ & $(0.402)$ & \\
\hline \multirow[t]{2}{*}{ Adj } & 0.174 & -0.340 & -0.329 & & & & & \\
\hline & $(0.304)$ & $(0.450)$ & $(0.445)$ & & & & & \\
\hline \multirow[t]{2}{*}{ Mercosul } & $0.641^{* k * k}$ & -1.581 & $-2.958 * *$ & & & & & \\
\hline & $(0.215)$ & (1.114) & (1.182) & & & & & \\
\hline \multirow[t]{2}{*}{ Nafta } & $-1.123^{* k *}$ & -2.515 & $-5.351 * *$ & & & & & \\
\hline & $(0.266)$ & $(2.300)$ & $(2.222)$ & & & & & \\
\hline \multirow[t]{2}{*}{ UE } & $-0.338^{*}$ & -1.871 & $-3.459^{* * *}$ & & & & & \\
\hline & $(0.184)$ & $(1.254)$ & $(1.281)$ & & & & & \\
\hline \multirow[t]{2}{*}{ Lndistance } & $-0.765^{* * *}$ & $-1.144^{\text {*w*k }}$ & $-1.153^{* * * k}$ & & & & & \\
\hline & $(0.163)$ & $(0.384)$ & $(0.383)$ & & & & & \\
\hline \multirow[t]{2}{*}{ WPI } & & & & & & & 0.718 & \\
\hline & & & & & & & $(2.223)$ & \\
\hline \multirow[t]{2}{*}{ lnroad_ext_t-1 } & & & & & & & & $-0.648^{* *}$ \\
\hline & & & & & & & & $(0.303)$ \\
\hline \multirow[t]{2}{*}{ PI_t-1 } & & & & & & & & $10.15^{* *}$ \\
\hline & & & & & & & & $(4.230)$ \\
\hline \multirow[t]{2}{*}{$\operatorname{lngdp1} 1$ lngdp2_t-1 } & & & & & & & & -0.0161 \\
\hline & & & & & & & & $(0.0143)$ \\
\hline \multirow[t]{2}{*}{ lnpop1_lnpop2_t-1 } & & & & & & & & 0.786 \\
\hline & & & & & & & & (4.104) \\
\hline Observations & 3240 & 3240 & 3240 & 3104 & 3104 & 3240 & 3104 & 2304 \\
\hline Number of panel_id & & & & 776 & 776 & 810 & 776 & 768 \\
\hline Year F.E. & YES & YES & YES & YES & YES & YES & YES & YES \\
\hline Country F.E. & NO & YES & YES & NO & NO & NO & $\mathrm{NO}$ & NO \\
\hline State F.E. & NO & YES & YES & NO & NO & NO & NO & NO \\
\hline Country-by-year F.E. & NO & NO & YES & YES & YES & YES & YES & YES \\
\hline Region-by-year F.E. & NO & NO & NO & NO & YES & YES & YES & YES \\
\hline Country-by-state F.E. & NO & NO & NO & YES & YES & YES & YES & YES \\
\hline
\end{tabular}

Robust standard errors clustered at the country-state level in parentheses. Columns 1-5 and 7-8 estimated by Poisson Pseudo maximum-likelihood. Model 6 estimated by OLS.

infrastructures. For this reason, we have grouped Brazilian countries into five regions (North, Northeast, Southeast, South and CenterWest) and included regions-by year fixed effects. This strategy should allow us to capture variation over time in regional unobserved heterogeneity associated to possible regional business cycles or regional specific trade shocks, while still allowing us to identify the impact of port infrastructures on exports (see, for a similar approach, Bratti et al. (2014)).

Conditionally on the inclusion of these sets of fixed effects, we aim to identify the causal impact of port infrastructure on trade. Moreover, in order to further alleviate possible remaining endogeneity concerns, we also estimate a version of our gravity equation where all main variables are lagged one period and we perform the test for strong exogeneity for fixed effects models proposed by Wooldridge (2010).

Finally, it is important to observe that, because of the inclusion of fixed effects, we identify the impact of port infrastructure on Brazilian imports and exports only from the within Brazilian state variation over time. Although in our sample most of the variation in port infrastructures is across Brazilian states, the within variation is not negligible, at the light of the significant public investment programmes aimed to remove bottlenecks in some ports in various Brazilian states over the sample period considered in this study, as discussed in Section 2 above.

\section{Empirical results}

In Table 6 and 7 we report a set of regression results for Brazilian exports and imports, respectively. We focus first on exports. In the first column, we report results for a "first generation" gravity equation model estimated with a Poisson pseudo maximumlikelihood estimator, with no fixed effects, with the exception of a set of "common" year fixed effects. Empirical results show that the port infrastructure variable has a positive coefficient, although it is largely statistically insignificant. As far as the other control variables are concerned, we note that the log of the product of GDPs is positive, statistically significant and with a coefficient very close to one. Among the other significant regressors, our findings confirm the typical results in gravity equations, namely that distance is associated to lower trade; moreover, we note that countries/states more populated trade more with each other. 
Table 7

Regression results for import.

\begin{tabular}{|c|c|c|c|c|c|c|}
\hline VARIABLES & $\begin{array}{l}\text { (1) } \\
\text { Import }\end{array}$ & $\begin{array}{l}(2) \\
\text { Import }\end{array}$ & $\begin{array}{l}\text { (3) } \\
\text { Import }\end{array}$ & $\begin{array}{l}\text { (4) } \\
\text { Import }\end{array}$ & $\begin{array}{l}\text { (5) } \\
\operatorname{Ln}(1+\text { Import })\end{array}$ & $\begin{array}{l}(6) \\
\text { Import }\end{array}$ \\
\hline lnroad_ext & $\begin{array}{l}-0.119 \\
(0.125)\end{array}$ & $\begin{array}{l}0.0965^{*} \\
(0.0584)\end{array}$ & $\begin{array}{l}0.0884^{*} \\
(0.0494)\end{array}$ & $\begin{array}{l}-0.0202 \\
(0.0730)\end{array}$ & $\begin{array}{l}0.781 \\
(0.493)\end{array}$ & \\
\hline CaisExt2 & $\begin{array}{l}0.922 \\
(1.029)\end{array}$ & $\begin{array}{l}1.554 \\
(3.908)\end{array}$ & $\begin{array}{l}0.115 \\
(2.974)\end{array}$ & $\begin{array}{l}1.849 \\
(2.924)\end{array}$ & $\begin{array}{l}13.75 \\
(19.71)\end{array}$ & \\
\hline lngdp1_lngdp2 & $\begin{array}{l}0.954^{* k \times k} \\
(0.0907)\end{array}$ & $\begin{array}{l}-0.143^{*} \\
(0.0743)\end{array}$ & $\begin{array}{l}0.0110 \\
(0.0112)\end{array}$ & $\begin{array}{l}0.0155 \\
(0.0133)\end{array}$ & $\begin{array}{l}-0.0372 \\
(0.359)\end{array}$ & \\
\hline lnpop1_lnpop2 & $\begin{array}{l}0.136 \\
(0.0856)\end{array}$ & $\begin{array}{l}0.962^{*} \\
(0.572)\end{array}$ & $\begin{array}{l}0.0514 \\
(0.410)\end{array}$ & $\begin{array}{l}-0.267 \\
(0.383)\end{array}$ & $\begin{array}{l}-0.125 \\
(1.139)\end{array}$ & \\
\hline Adj & $\begin{array}{l}1.348^{\text {*k/k }} \\
(0.271)\end{array}$ & $\begin{array}{l}1.070^{* * x} \\
(0.394)\end{array}$ & & & & \\
\hline Mercosul & $\begin{array}{l}0.516 \\
(0.415)\end{array}$ & $\begin{array}{l}1.590 \\
(1.108)\end{array}$ & & & & \\
\hline Nafta & $\begin{array}{l}-0.839^{* k * *} \\
(0.268)\end{array}$ & $\begin{array}{l}1.592 \\
(2.029)\end{array}$ & & & & \\
\hline UE & $\begin{array}{l}-0.313 \\
(0.235)\end{array}$ & $\begin{array}{l}0.737 \\
(1.144)\end{array}$ & & & & \\
\hline lndistance & $\begin{array}{l}-0.658^{\text {**** }} \\
(0.215)\end{array}$ & $\begin{array}{c}-0.341 \\
(0.440)\end{array}$ & & & & \\
\hline lnroad_ext_t-1 & & & & & & $\begin{array}{l}0.195 \\
(0.139)\end{array}$ \\
\hline PI_t-1 & & & & & & $\begin{array}{l}7.668^{k *} \\
(3.436)\end{array}$ \\
\hline lngdp1_lngdp2_t-1 & & & & & & $\begin{array}{l}0.00884 \\
(0.00893)\end{array}$ \\
\hline Inpop1_lnpop2_t-1 & & & & & & $\begin{array}{l}-4.464 \\
(2.984)\end{array}$ \\
\hline Constant & $\begin{array}{l}-30.92^{* k * k} \\
(3.575)\end{array}$ & $\begin{array}{c}-9.502 \\
(17.56)\end{array}$ & & & & \\
\hline Observations & 3240 & 3240 & 3076 & 3076 & 3240 & 2292 \\
\hline Number of panel_id & & & 769 & 769 & 810 & 764 \\
\hline Year F.E. & YES & YES & YES & YES & YES & YES \\
\hline Country F.E. & NO & YES & NO & NO & NO & NO \\
\hline State F.E. & NO & YES & $\mathrm{NO}$ & NO & NO & NO \\
\hline Country-by-year F.E. & NO & NO & YES & YES & YES & YES \\
\hline Region-by-year F.E. & NO & NO & NO & YES & YES & YES \\
\hline Country-by-state F.E. & NO & NO & YES & YES & YES & YES \\
\hline
\end{tabular}

Robust standard errors clustered at the country-state level in parentheses. Columns 1-4 and 6 estimated by Poisson Pseudo maximum-likelihood. Model 5 estimated by OLS.

Among free trade areas agreements, we note that Brazilian states tend to export more to countries belonging to the Mercosul agreement, and less to Nafta and EU countries. ${ }^{11}$ Finally, we surprisingly find that roads are negatively associated to exports, although we will see this result is not very robust across specifications. ${ }^{12}$

In the next columns we start including some of the fixed effects considered in Eq. (6). In particular, in column 2 we add separate exporter and importer fixed effects: for the port infrastructure variable, this means that we are identifying its impact through the within Brazilian state variation over time. We can note that its coefficient is now much larger and statistically significant at $1 \%$ level.

In turn, the GDP coefficient is now much lower, but still statistically significant. Among the other regressors, only distance continues to have a statistically significant effect. In column 3 we let importer (i.e. foreign countries) fixed effects to change over time by including importer-by-year fixed effects, while in column 4 we also add importer-exporter fixed effects, and in column 5 also a full set of Brazilian regions-by-year fixed effects ${ }^{13}$ : reassuringly, the coefficient of the port infrastructure variable remains pretty stable and statistically significant.

In turn, in column 6 we estimate by $O L S$ a log linear version of the equation reported in column 5 by adding 1 to the export variable: in this case, the coefficient of port infrastructure is negative, but largely insignificant. Even if, as shown by Santos Silva and

\footnotetext{
11 This is partially due to the fact that Brazil has a preferential trade agreement with Mercosul countries and not with Nafta and EU countries.

12 One explanation for a negative coefficient of the road variable might be linked to possible measurement error bias. In fact, it is reasonable to think that different types of roads, such as motorways or rural roads, have a differential effect on trade, but unfortunately we do not have information on roads characteristics and on their quality, such as number of lines, etc. Suppose that during our sample period there was a stronger increase in roads in Brazilian States with declining exports, but this increase in roads was of a very poor type, while for other States experiencing a smaller increase in roads that increase mainly concerned high quality roads. In this scenario we believe it is reasonable to think that the coefficient of roads would have a negative bias in our regressions.

${ }^{13}$ It is important to note that in these regressions the coefficient of log GDP and log population are identified only through the GDP and population variation within Brazilian states, because the variation over time in importing countries is entirely captured by the importer-by-year fixed effects. Results are robust to dropping both $\log$ GDP and $\log$ population variables.
} 
Tenreyro (2006), results obtained from the Poisson should be preferred on theoretical grounds, as a robustness check we have implemented the RESET test for misspecification suggested by the same authors. In particular, for both regressions reported as column 5 and 6 we have computed the fitted values, which have then been included in squared form into the respective regressions: statistically significant coefficients of squared fitted values is a signal of model misspecification. We find that, ${ }^{14}$ while in the case of the Poisson model (column 5) we cannot reject at the $10 \%$ level the null hypothesis that squared residuals are equal to zero, we fail to reject the null hypothesis, at whatever confidence level, in the case of the log-linear model, thus concluding that the latter might indeed be misspecified.

In column 7 we explore the existence of possible spillover effects of ports, by including in the same specification of column 5 , the spatial lag of port infrastructure (WPI), where the matrix of weights is of the contiguity type. Regression results suggest that the spatial lag of port infrastructure has a positive coefficient, pointing towards the existence of positive spillovers, although the effect is imprecisely estimated. Nevertheless, it seems fair to say that this issue should be explored more deeply, such as by using appropriate spatial econometric techniques. ${ }^{15}$

Finally, in column (8) we seek to alleviate additional endogeneity concerns by including all variables lagged one period: as we can see, the impact of port infrastructure remains positive and statistically significant, but with a coefficient that is more than halved.

As discussed in Section 3 above, one of the empirical strategy we adopted to address possible endogeneity issues, has been to relay on a set of fixed effects. In particular, the export-importer fixed effects control for any unobserved determinant of both exports and Brazilian port infrastructures; moreover, the Brazilian region-by-year fixed effects also take into account unobserved time-varying shocks that drive both exports and the expansion of port infrastructure that are common within a Brazilian region. Nevertheless, one could still have concerns of possible simultaneity between ports infrastructures and trade even after accounting for this wide set of fixed effects. ${ }^{16}$ In order to test the reliability of our results, we have carried out the strong exogeneity test proposed by Wooldridge (2010). Indeed, in a panel model with fixed effects, $P I_{i t}$ should be uncorrelated with the error term at all lags and leads ${ }^{17}$ : therefore, Wooldridge (2010) suggests including lags and leads (i.e. anticipatory effects) in the regression. While the statistical significance of a lag is not problematic because we could re-interpret the equation as a distributed lag one, a statistically significant lead is likely to capture some underlying trend that could make our results suspicious. We have therefore re-run our most extended and general specification (Model 5) including one lag and one lead of port infrastructures. Results, not shown but available upon request, suggest that neither the lag nor the lead are statistically significant at conventional levels of confidence: reassuringly, the coefficient of $P I_{i t}$ is still negative, significant at $10 \%$ and with a magnitude of about 14, which is in the lower range of the estimates presented in Table 6 .

All in all, empirical results reported in Table 6 shows that, in the case of Poisson regressions, once we include at least importer and exporter fixed effects, port infrastructures are positively associated to exports of Brazilian states. As far as the magnitude of the impact is concerned, it is important to note that coefficient of regressors that enter linearly into the Poisson regression equation can be interpreted as semi-elasticities (Wooldridge, 2010). Therefore, we can evaluate the impact of port infrastructure with the following virtual experiment: let us assume that port infrastructures are increased from the median of its distribution (0.0024) to the 75th percentile (0.0299). ${ }^{18}$ In this case exports would increase by about $68 \%{ }^{19}$ : this is a very large effect, probably outside the range one could judge realistic. However, if we consider estimates reported as column $8,{ }^{20}$ the impact would be much smaller and close to $28 \%$. It is important to acknowledge that the change in the stock of port infrastructure considered in this example is indeed a very large change, far bigger than any increase in port infrastructure experienced by a Brazilian state over our sample period.

If we consider the largest port extension in our sample period (which corresponds to an increase in the port infrastructure variable of 0.014 ), the associated impact on exports could have been as large as $14 \%$, if we consider our most conservative estimate in column 8. Finally, the effect of the stock of roads does not turn out to be very robust: the effect is largely negative, although in general it is not statistically significant. After having discussed the export regressions we now turn to Table 7, where we examine the case of imports of Brazilian states. As we can see, the impact of ports is very small and largely insignificant. ${ }^{21}$ Only when we consider the lagged model (column 6, corresponding to column 8 in Table 6), we find a positive and statistically significant effect of port infrastructure. In this case, an increase in the port infrastructure of 0.014 (the largest increase in a given year experienced by a Brazilian state), would be associated to an increase in Brazilian imports of about 11\%. Again, as in the case of exports, the effect of roads is not very robust across models, although in a few cases is positive and statistically significantly so.

All in all, our empirical results suggest that, if we estimate a gravity equation by a Poisson pseudo maximum likelihood estimator and we control for a wide set of fixed effects, port infrastructures seem to be positively correlated with trade. Moreover, the effect is large and robust in the case of exports, while it is smaller and less robustly estimated in the case of imports.

A few words should be spent on the way we measure ports in this study. Indeed, one could argue that port infrastructures can be a poor proxy for port activity. In a somewhat extreme scenario, the port facilities could be unutilized: considering a variable that jointly considers port infrastructure, as well as its efficiency of use, might provide a better proxy for port activity. However, modifying our

\footnotetext{
${ }^{14}$ Results are available from the authors upon request.

15 For a paper analysing the impact of ports on economic activity using spatial econometric techniques, see Bottasso et al. (2014).

16 To the best of our knowledge, ours is the only study seeking to estimate the impact of port infrastructure on trade employing the widest set of fixed effects.

17 In other words, the port infrastructure variable in year $t$ variable needs to be uncorrelated with the error terms in any year $s \neq t$.

${ }^{18}$ Let us recall that the port infrastructure variable is expressed as the length of port piers in a Brazilian state normalized by that state's area. Moreover, about $40 \%$ of our observations display a zero level of port infrastructure.

19 This is derived as follows: $25 *(0.0299-0.0025) * 100$.

${ }^{20}$ Or the estimates we get when we include lags and leads.

${ }^{21}$ In Table 7 we report fewer regressions with respect to export estimates because in some we experienced convergence problems.
} 
physical proxies with indicators for efficiency and productivity of ports would introduce serious endogeneity concerns, given that any of these indicators would be based on port outputs in each Brazilian state, which surely depends on that state intensity of trade. By way of contrast, the expansion of port infrastructures is less likely to be related to demand developments and trade, and therefore more likely to be exogenous in our setting.

We believe it might be important to relate our findings to the previous literature. As discussed in the introduction, only few papers sought to assess the impact of transportation infrastructure on trade; moreover, port infrastructures were generally considered as parts of more aggregate indicators, thereby making a direct comparison with our paper extremely difficult. We can only mention three papers that are more amenable to a direct comparison with ours. The first is the study by Wilson et al. (2005), who show that composite indicators of port and air transport facilities (mixed together) of both importers and exporters are positively correlated with bilateral trade in a large sample of countries: however, their empirical models are estimated by OLS and authors fail to jointly control for importer and exporters fixed effects. In turn, Bensassi et al. (2015) estimate a gravity equation for a panel of Spanish regions in order to evaluate the impact of both transport infrastructure and the logistics system on trade. In some regression specifications authors find that the efficiency of the port industry (measured as regional ports productivity) or, alternatively, the extent of regional port facilities (measured as the percentage of sea traffic in a region over total traffic in Spain) is positively correlated with trade. However, their model does include neither Spanish regions-by-year fixed effects, nor regions-country fixed effects. Finally, Marquez-Ramos (2016) estimated gravity equations for a set of Spanish regions and found evidence that ports facilities in a region as well as in neighbourhood ones are positively correlated with exports.

\section{Conclusion}

This study focuses on an important issue such as the relation between trade and transport infrastructure, mainly considering port infrastructure endowment. Our estimates of a gravity equation on a panel of Brazilian states observed over the period 2009-2012 confirm the links between international trade, GDP, population and distance, but they also show the capability of port endowment to foster international trade flows. The positive impact of port infrastructure on trade is found to be higher for export flows with respect to imports: in particular, estimates suggest that maritime infrastructure investments realized over the sample period have generated an increase of about $14 \%$ for export and $11 \%$ for import flows. This result might be connected to the different logistics services - and related transport organization - that "export oriented" activities (e.g. soy, fuel, and iron ore) need in comparison with "import related" flows. Moreover, the presence of the biggest Brazilian firms in all main bulk exporting sectors (e.g. Vale for the iron one, Petrobras for oil) that are often acting also as integrated transport companies (e.g. investing in terminal facilities) might have increased the positive effects of export related activities on local economies.

Another interesting result of this study is related to spillover effects: estimates provide evidence in favor of the existence of positive spillover effects of ports, although such effect is imprecisely estimated. The possible existence of spillovers underlines the link between port infrastructure and other landlocked regions and suggest the possibility to foster their international trade through more efficient connections among main production/consumption points and ports.

Our empirical results do not provide evidence in favor of a positive effect of roads infrastructure endowments on international trade flows. Such result might be associated to the out-of-date status of many internal roads that in some cases can generate extra costs and might negatively affect trade operations. This aspect is also underlined by the previous literature that investigated the Brazilian logistics system (e.g. Ng et al., 2013; Wanke, 2013).

Although the analysis might be improved from different points of view, we believe that overall results provide support in favor of the implementation of policy intervention aimed at the expansion of port infrastructure. Moreover, it seems that the positive impact of such investments on trade flow might be reinforced by complementary investments designed at improving and developing other transport infrastructure, like roads. Such investments, by increasing connectivity and reducing transport costs, might be able to reinforce and amplify spillover effects between maritime and non-maritime regions. Indeed, these results are in line with other studies (e.g. Galvão et al., 2017; Wanke et al., 2011) that suggest the need of improving Brazilian port efficiency (and endowment).

Limitations of the model do not allow us to identify possible specific trade patterns (or commodities) that might generate the main benefits, weakening the possibility to suggest specific interventions for main Brazilian policy makers. Nevertheless, our analysis underlines the clear contribution of the Brazilian port system to the national economic growth and how potential improvements in the port transport and logistics system could generate major benefits for the local economies.

In order to increase the quality of the proposed research, future developments will focus on comparing different realities and trade patterns, investigating the role of the overall transport system on the Brazilian trade structure and on specific regions.

\section{References}

American Association of Port Authorities, 2017. Port Statistics Database. $<$ http://www.aapa-ports.org/unifying/content.aspx? ItemNumber = 21048 > .

Andreson, J.E., van Wincoop, E., 2003. Gravity with gravitas: a solution to the border puzzle. Am. Econ. Rev. 93 (1), $170-192$.

ANTAQ, 2017. Agência National de Transportes Aquaviários. < http://portal.antaq.gov.br/ >

Arbués, P., Baños, J.F., Mayor, M., 2015. The spatial productivity of transportation infrastructure. Transp. Res. Part A: Policy Pract. 75, 166-177.

Arvis, J.F., Mustra, M.A., Ojala, L., Saslavsky, D., 2012. Connecting to Compete 2012 Trade Logistics in the Global Economy - The Logistics Performance Index and Its Indicators. International Trade Department, The World Bank, Washington, United States.

Baldwin, R., Taglioni, D., 2006. Gravity for Dummies and Dummies for Gravity Equations. NBER Working Paper Series, 12516.

Barros, C.P., Gil-Alana, L.A., Wanke, P., 2015. An empirical analysis of freight transport traffic modes in Brazil, 1996-2012. Transp. Plan. Technol. 38, 305-319. Bensassi, L., Marquez-Ramos, L., Martinez-Zarzoso, I., Suarez-Burguet, C., 2015. Relationship between logistic infrastructure and trade: evidence from Spanish regional exports. Transp. Res. Part A 72, 47-71. 
Boehe, D.M., Qian, G., Peng, M.W., 2016. Export intensity, scope, and destinations: evidence from Brazil. Ind. Mark. Manage. 57, $127-138$.

Bottasso, A., Conti, M., Ferrari, C., Tei, A., 2014. Ports and regional development: a spatial analysis on a panel of European regions". Transp. Res. Part A 65, 44-55. Bottasso, A., Conti, M., Ferrari, C., Merk, O., Tei, A., 2013. The impact of port throughput on local employment: evidence from a panel of European regions. Transp. Policy 27, 32-38.

Bratti, M., De Benedicts, L., Santoni, G., 2014. On the pro-trade effects of migrants. Rev. World Econ. 150, 557-594.

Calatayud, A., Mangan, J., Palacin, R., 2017. Connectivity to international markets: a multi-layered network approach. J. Transp. Geogr. 61 , 61-71.

Camagni, R., Capello, R., 2013. Regional competitiveness and territorial capital: a conceptual approach and empirical evidence from the European Union. Reg. Stud. 47, 1383-1402.

Cassey, A.J., 2011. State foreign export patterns. South. Econ. J. 78, 308-329.

Celbis, M.G., Nijkamp, P., Poot, J., 2014. Infrastructure and trade: a meta-analysis. Region 1, $25-65$.

CIA - Central Intelligence Agency, 2017. The World Factbook, Washington, United States.

Cizkowicz, P., Rzonca, A., Uminski, S., 2013. The determinants of regional exports in Poland - a panel data analysis. Post-Communist Econ. 25 , 206-224.

Clark, X.M., Dollar, D., Micco, A., 2004. Port efficiency, maritime transport costs, and bilateral trade. J. Dev. Econ. 75, 417-450.

CNT - Confederação Nacional do Transporte, 2016. Pesquisa Nacional de Rodovias, Brasília, Brasil.

Coşar, A.K., Demir, B., 2016. Domestic road infrastructure and international trade: evidence from Turkey. J. Dev. Econ. 118, $232-244$.

Ducruet, C., Itoh, H., 2016. Regions and material flows: investigating the regional branching and industry relatedness of port traffics in a global perspective. J. Econ. Geogr. 16, 805-830.

Ducruet, C., Notteboom, T., 2012. The worldwide maritime network of container shipping: spatial structure and regional dynamics. Glob. Netw. 12, 395-423.

Duranton, G., 2015. Roads and trade in Colombia. Econ. Transp. 4, 16-36.

Egger, P., Staub, K., 2016. GLM estimation of trade gravity models with fixed effects. Empirical Econ.

Fally, T., 2015. Structural gravity and fixed effects. J. Int. Econ. 9, 76-85.

Fleury, P.F., Hijjar, M.F., 2008. Logistics Overview in Brazil 2008. Instituto de Logística e Supply Chain. < http://www.guiadotrc.com.br/logistica/Logistics_ Overview_in_Brazil_2008.pdf $>$.

Galvão, C.B., Robles, L.T., Guerise, L.C., 2017. 20 years of port reform in Brazil: insights into the reform process. Res. Transp. Bus. Manage. 22, 153-160.

Garcia-Escribano, M., Góes, C., Karpowicz, I., 2015. Filling the Gap: Infrastructure Investment in Brazil. IMF Working Paper, n. 15/180, Available at SSRN: < https:// ssrn.com/abstract $=2659537>$.

Graham, B., 1998. Liberalization, regional economic development and the geography of demand for air transport in the European Union. J. Transp. Geogr. 6, 87-104.

Guerrero, D., Grasland, C., Ducruet, C., 2016. Explaining international trade flows with shipping distances. In: Ducruet, C. (Ed.), Maritime Networks: Spatial Structures and Time Dynamics. Routledge, New York, United States.

Haddad, E.A., Hewings, G.J.D., Perobelli, F.S., dos Santos, R.A.C., 2010. Regional effects of port infrastructure: a spatial CGE application to Brazil. Int. Reg. Sci. Rev. 33 (3), 239-263.

Hall, P.V., 2009. Container ports, local benefits and transportation worker earnings. GeoJournal 74, 67-83.

Handy, S., 2005. Smart growth and the transportation-land use connection: what does the research tell us? Int. Reg. Sci. Rev. $28,146-167$.

Head, K., Mayer, T., 2015. Gravity equations: workhorse, toolkit, and codebook. In: Gopinath, G., Helpman, E., Rogoff, K. (Eds.), Handbook of International Economics, vol. 4. Elsevier.

Hesse, M., Rodrigue, J.P., 2006. Global production networks and the role of logistics and transportation. Growth Change 37, $499-509$.

Hopewell, K., 2015. Different paths to power: the rise of Brazil, India and China at the World Trade Organization. Rev. Int. Polit. Econ. 22, $311-338$.

International Monetary Fund, 2017. www.imf.org.

Li, K., Qi, G., 2016. Transport connectivity and regional development in China. J. Int. Logist. Trade 14, $142-155$.

Limao, N., Venables, A.J., 2001. Infrastructure, geographical disadvantage, transport cost, and trade. World Bank Econ. Rev. 15, 451-479.

Marquez-Ramos, L., 2016. Port facilities, regional spillovers and exports: empirical evidence from Spain. Pap. Reg. Sci. 95 (2), $329-351$.

Martínez-Zarzoso, I., García-Menéndez, L., Suárez-Burguet, C., 2003. Impact of transport costs on international trade: the case of Spanish ceramic exports. Marit. Econ. Logist. 5, 179-198.

Matthee, M., Naudé, W., 2008. The determinants of regional manufactured exports from a developing country. Int. Reg. Sci. Rev. 31, 343-358.

Merk, O., 2012. The Competitiveness of Global Port-Cities: Synthesis Report. Organization for the Economic Cooperation and Development, Paris.

Moreno, R., Lopez-Bazo, E., 2007. Returns to local and transport infrastructure under regional spillovers. Int. Reg. Sci. Rev. 30, 47-71.

Ng, A.K.Y., Gujar, G.C., 2009. Government policies, efficiency and competitiveness: the case of dry ports in India. Transp. Policy 16, $232-239$.

Ng, A.K.Y., Padilha, F., Pallis, A.A., 2013. Institutions, bureaucratic and logistical roles of dry ports: the Brazilian experiences. J. Transp. Geogr. 27, 46-55.

Nuñez, H., Önal, H., 2016. An economic analysis of transportation fuel policies in Brazil: fuel choice, land use, and environmental impacts. Energy Econ. 55, 319-331.

Olarreaga, M., 2016. Trade, Infrastructure, and Development, ADBI Working Paper Series n. 626. Asian Development Bank Institute, Tokyo, Japan.

Organization of the Economic Cooperation and Development, 2016. World Trade Statistical Review 2016. OECD Publishing, Paris, France.

Portugal Perez, A., Wilson, J.S., 2012. Export performance and trade facilitation reform: hard and soft infrastructure. World Dev. $40,1295-1307$.

Purwanto, J., 2010. Impact of Transport Infrastructure on International Competitiveness of Europe. < https://www.i-c-eu.eu/ > .

Redding, S., Turner, M., 2017. Transportation costs and the spatial organization of economic activity. In: In: Duranton, G., Henderson, J., Strange, W. (Eds.), Handbook of Regional and Urban Economics, vol. 5 Elsevier, Amsterdam.

Rodrigue, J.P., Comtois, C., Slack, B., 2016. The Geography of Transport Systems. Routledge, New York.

Santos Silva, J., Tenreyro, S., 2006. The log of gravity. Rev. Econ. Stat. 88 (4), 641-658.

Sá Porto, P.C., Oliveira, A.L.R., Ferrari, C., Puliafito, P.P., Tei, A., Chirco, M., 2014. Short shipping services in Brazil: insights for a market analysis. In: Proceedings of the EURAM 2014 Conference, June 2014, Valencia, Spain.

Song, L., van Geenhuizen, M., 2014. Port infrastructure investment and regional economic growth in China: panel evidence in port regions and provinces. Transp. Policy 36, 173-183.

Tiller, K.C., Thill, J.C., 2017. Spatial patterns of landside trade impedance in containerized South American exports. J. Transp. Geogr. 58, $272-285$.

Tinbergen, J., 1962. Shaping the world economy: Suggestions for an international economic policy. Twentieth Century Fund, New York.

Unctad - United Nation Conference on Trade and Development, 2016. Review on Maritime Transport, Genève, Switzerland.

Vickerman, R., 1995. Location, accessibility and regional development: the appraisal of trans-European networks. Transp. Policy 2, $225-234$.

Wang, C., Chen, Q., Huang, R., 2017. Locating dry ports on a network: a case study on Tianjin Port. Marit. Policy Manage. http://dx.doi.org/10.1080/03088839.2017. 1330558.

Wanke, P.F., 2013. Physical infrastructure and shipment consolidation efficiency drivers in Brazilian ports: a two-stage network-DEA approach. Transp. Policy 29, $145-153$.

Wanke, P.F., Zinn, W., 2004. Strategic logistics decision making. Int. J. Phys. Distrib. Logist. Manage. 34, 466-478.

Wanke, P.F., Barbastefano, R.G., Hijjar, M.F., 2011. Determinants of efficiency at major Brazilian port terminals. Transp. Rev. $31,653-677$.

Wilmsmeier, G., Hoffmann, J., 2008. Liner shipping connectivity and port infrastructure as determinants of freight rates in the Caribbean. Marit. Econ. Logist. 10, $130-151$.

Wilmsmeier, G., Hoffmann, J., Sanchez, R., 2006. The impact of port characteristics on international maritime transport costs. In: Cullinane, K., Talley, W. (Eds.), Port Economics, Research in Transportation Economics, 16. Elsevier, Amsterdam.

Wilson, J.S., Mann, C.L., Otsuki, T., 2005. Assessing the benefits of trade facilitation: a global perspective. World Econ. 28, 841-871.

Wooldridge, J., 2010. Econometric Analysis of Cross Section and Panel Data, second ed. The MIT Press.

World Bank, 2017a. Logistics Performance Index. < https://lpi.worldbank.org/ > .

World Bank, 2017b. Doing Business Report. < http://www.doingbusiness.org/ >

World Bank, 2012. Doing Business: Measuring Business Regulations. The World Bank, Washington, United States. 